\title{
A reforma agrária nos campos do sul de Portugal (1975): uma revolução na revolução
}

\author{
Land reform in the fields of southern Portugal (1975): \\ a revolution in the revolution
}

\author{
La reforma agraria en los campos del sur de \\ Portugal (1975): una revolución en la revolución
}

\author{
Raquel Varela* \\ Constantino Piçarra**
}

\begin{abstract}
Resumo: Realizado a 25 de abril de 1974, depressa o golpe de Estado que derruba a ditadura origina um processo revolucionário no âmbito do qual, no sul de Portugal, a agudização da luta por melhores salários, condições de trabalho e garantia de emprego, entre assalariados rurais, com especial realce para os temporários, e os empresários agrícolas, dá lugar a um poderoso movimento de ocupações de terras, fato que torna realidade a reforma agrária, cujo enquadramento legal só vem a surgir na vigência dos IV e V Governos Provisórios liderados por Vasco Gonçalves, tendo Fernando Oliveira Baptista na pasta da Agricultura. Neste processo de ocupações de terras, que se desenrola ao longo do ano de 1975, definem-se três fases, as quais se caracterizam em articulação com o andamento da situação política do país e, por conseguinte, com a política agrária do Estado ao longo deste período. Utilizamos uma ampla gama de fontes, algumas inéditas como a documentção dos partidos políticos, as fontes dos sindicatos e comissões de trabalhadores, as disposições legais referentes ao processo e o arquivo de imagem da televisão pública RTP. Destacamos neste artigo duas conclusões principais a partir da investigação que levamos a cabo: 1) a reforma agrária é um processo que se inicia por ocupações espontâneas de terras e os partidos políticos irão responder a este processo tentando dirigi-lo; 2) a reforma agrária é determinada por um modelo assente em unidades coletivas de produção e na maximização do emprego.
\end{abstract}

Palavras-chave: Portugal; reforma agrária; partido comunista; propriedade

\footnotetext{
* Investigadora do Instituto de História Contemporânea da Universidade Nova de Lisboa. $<$ raquel_cardeira_varela@yahoo.co.uk>

** Historiador. Professor do ensino secundário e bibliotecário de leitura pública.<constantino.p@, sapo.pt $><$ dados biográficos/biographic data $>$
} 


\begin{abstract}
Held on April 25, 1974, soon the coup that overthrew the dictatorship led to a revolutionary process under which, in southern Portugal, the intensification of the struggle for better wages, working conditions and job security among rural workers, with particular emphasis on the casual workers and the farmers, gave rise to a powerful movement of land occupations, something that makes agrarian reform effective - its legal framework will happen only with the fourth and fifth Provisional Governments led by Vasco Gonçalves, with Fernando Oliveira Baptista as the secretary of Agriculture. In this process of land occupations, which takes place throughout the year 1975, there are three phases, characterized in connection with the progress of the political situation in the country and, therefore, with the agrarian policy of the state over this period. We use a wide range of sources, some new as the documentation of political parties, the sources of trade unions and workers' councils, the legal provisions regarding the process and the image bank of the public television, RTP. We highlight in this article two main conclusions from the research that we've carried: 1) agrarian reform is a process that begins with the spontaneous occupations of land and the political parties will respond to this process trying to control it; 2) land reform is determined by a model based on collective production units and maximizing employment in rural areas.
\end{abstract}

Keywords: Portugal; land-reform; communist party; property

Resumen: Ocurrido el 25 de abril de 1974, rápidamente el golpe de Estado que derrocó a la dictadura llevó a un proceso revolucionario en virtud del cual, en el sur de Portugal, la intensificación de la lucha por mejores salarios, condiciones de trabajo y seguridad en el empleo entre los trabajadores rurales, con especial incidencia en el trabajo temporal y los grandes agricultores, dio lugar a un poderoso movimiento de ocupaciones de tierras, algo que hizo realidad la reforma agraria, cuyo marco legal sólo vio la luz en la vigencia del IV y V gobiernos provisionales encabezados por Vasco Gonçalves, con Fernando Oliveira Baptista en el ministerio de Agricultura. En este proceso de ocupación de tierras, que se lleva a cabo durante todo el año 1975, se definen tres fases, que se caracterizan en relación con el progreso de la situación política del país y, por lo tanto, la política agraria del Estado durante este período. Utilizamos una amplia gama de fuentes, algunas nuevas como la documentación de los partidos políticos, las fuentes de los sindicatos y los comités de empresa, las disposiciones legales referentes al proceso y el archivo de imagen de la televisión pública, RTP. Destacamos en este artículo dos conclusiones principales de la investigación que hemos hecho: 1) la reforma agraria es un proceso que comienza por ocupaciones espontáneas de la tierra y los partidos políticos responden a este proceso tratando de conducirlo; 2) la reforma agraria está determinado por un modelo basado en las unidades de producción colectiva y en la maximización del empleo rural.

Palabras clave: Portugal; la reforma agraria; partido comunista; la propiedad

\title{
Introdução
}

Em simultâneo com as manifestações de alegria pela deposição da ditadura, as diversas classes da sociedade rural dos campos do sul de Portugal - pequenos agricultores, camponeses com trabalho fixo, assalariados rurais - começam a organizar-se com o objectivo de melhor defenderem os seus interesses no quadro político emergente do 25 de abril 
de 1974. Os primeiros a movimentar-se são paradoxalmente os grandes proprietários agrícolas que, liderados pelos empresários, constituem, em maio de 1974, a Associação Livre de Agricultores (ALA) e, numa espécie de defesa antecipada em relação a uma hipotética reforma agrária na zona do latifúndio, aprovam um programa onde preconizam a "função social da terra". Portanto, medidas destinadas «a impedir que haja terras mal exploradas"1.

Cerca de um mês depois, em junho, surgem as Ligas de Pequenos e Médios Agricultores procurando enquadrar e dar resposta aos anseios das classes intermédias do mundo rural do sul do país.

Apesar de não possuírem qualquer estrutura organizativa a data do 25 de abril de 1974 e das últimas lutas reivindicativas remontarem a 1962 (onde é conquistado o horário de trabalho diário de oito horas), os assalariados rurais, a partir de junho de 1974, constituem sindicatos de âmbito distrital, aprovam cadernos reivindicativos onde consta a exigência de aumentos salariais e a garantia de emprego, e iniciam, de imediato, um processo negocial, concelho a concelho, com os agricultores organizados na ALA. Destas negociações resultam a assinatura das primeiras convenções de trabalho rural, para vigorarem só durante o verão de 1974, as quais incluem a quase totalidade das reivindicações dos trabalhadores agrícolas. Por exemplo, no distrito de Beja, Alentejo - paredes meias com a Andaluzia -, sul de Portugal, os trabalhadores agrícolas conseguem, pela jornada de trabalho de 8 horas, $160 \$ 00$ para os trabalhadores gerais, homens, e $120 \$ 00$ para as mulheres, quando, em 1973, os valores praticados eram, respectivamente, de $80 \$ 00$ e $45 \$ 00$ (Estatísticas Agrícolas para o Distrito de Beja, 1976) e garantia de emprego para todos os homens e mulheres cabeça de casal.

Das negociações e do articulado destes primeiros acordos de trabalho assinados nos campos do sul de Portugal a seguir ao 25 de abril de 1974 surge claro que a questão que maior discórdia suscita é a que se relaciona com a solução do desemprego dos trabalhadores agrícolas. Perante a pretensão dos sindicatos em verem garantido emprego para todos os assalariados rurais, os grandes proprietários respondem a uma só voz que a questão do desemprego rural é um problema que os transcende, competindo ao governo solucioná-lo. Nesta conformidade, muitos destes agricultores colocam-se à margem do processo de distribuição de trabalhadores, forma encontrada de resolução do desemprego rural,

${ }_{1}$ Cf. Diário do Alentejo, de 27/05/74. 
invocando não só a ilegalidade destas distribuições, mas também a dos próprios acordos assinados.

Assim, quando em agosto/setembro de 1974, os sindicatos agrícolas avançam nos campos do sul para as negociações dos contratos coletivos de trabalho, de âmbito distrital, para vigorarem durante doze meses, encontram os grandes proprietários agrícolas irredutíveis na não aceitação de qualquer cláusula que os obrigue a resolver o desemprego dos assalariados rurais temporários.

Em Beja o sindicato consegue, no entanto, nos termos da convenção assinada em 29 de outubro de 1974, para vigorar até 30 de setembro de 1975, que os agricultores aceitem ficar sujeitos à colocação de mão-de-obra, nos casos em que as terras se encontrem em estado de subaproveitamento. Para tratar desta questão são criadas duas comissões, uma de âmbito concelhio, formada por trabalhadores e proprietários, para fiscalizar a situação de subaproveitamento das explorações agrícolas e colocar os trabalhadores, e outra de recurso, de âmbito distrital, integrando também representantes do governo.

O desemprego nos campos do sul é grande no outono de 1974, realidade agravada pela conjuntura da altura marcada pela vinda dos soldados das colónias portuguesas em África, pela quebra da emigração motivada pela crise petrolífera dos anos 70 e pelo regresso ao campo de muitos homens que se encontravam a trabalhar na construção civil na zona metropolitana de Lisboa, por força da crise então vivida por este sector da economia. Assim, perante a enorme pressão dos trabalhadores temporários, no sentido de verem a sua situação de desemprego resolvida, durante os meses de novembro e dezembro de 1974 são distribuídos no distrito de Beja, ao abrigo das cláusulas do Contrato Colectivo de Trabalho, assinado em 29 de outubro de 1974, mais de mil assalariados rurais pelas explorações agrícolas ${ }^{2}$, processo que é fortemente contestado pelos grandes proprietários que passam, em muitos casos, a não pagar os salários aos trabalhadores distribuídos e a furtar-se à realização de muitas tarefas agrícolas, enveredando, desta forma, pelo caminho da sabotagem económica.

A Secretaria de Estado da Agricultura dos primeiros três Governos Provisórios (abril de 1974 a março de 1975), liderada pelo Dr. Esteves Belo, que vem desenvolvendo, com o apoio da ALA, uma política agrícola virada para o aumento da produtividade (assente na reconversão

\footnotetext{
2 Cf. Relação dos trabalhadores distribuídos e relatório das comissões concelhias e distrital, constituídas nos termos do contrato coletivo de trabalho do distrito de Beja - Arquivo do Sindicato dos Trabalhadores Agrícolas do Distrito de Beja.
} 
capitalista da agricultura), perante este quadro de agudização dos conflitos sociais nos campos do sul é obrigada a intervir. Fá-lo pontualmente, ao abrigo do DL no 660/74 de 25 de novembro, nas explorações agrícolas onde os atos de descapitalização são mais significativos, nomeando um gestor público que passa a assumir o controle administrativo da empresa. Este decreto confere ao governo o direito de intervir, após inquérito, nas "empresas privadas individuais ou coletivas" que funcionem de forma a não "contribuir normalmente para o desenvolvimento económico do país".

A primeira intervenção do Estado português ao abrigo deste diploma legal ocorre no Monte do Outeiro, freguesia de Santa Vitória, concelho e distrito de Beja, em 22 de janeiro de 1975, fato que faz com que o problema da posse da terra ganhe, cada vez mais, espaço de discussão no seio dos assalariados rurais dos campos do sul, criando-lhes a convicção de que a resolução do desemprego se encontra em novas unidades de produção, geridas pelo Estado, constituídas a partir da expropriação do latifúndio e das grandes explorações capitalistas ${ }^{3}$.

Com centenas de trabalhadores colocados nas herdades sem receber salário, com milhares de temporários no desemprego e num contexto onde a luta pelo pleno emprego surge crescentemente ligada à expropriação do latifúndio e à realização da reforma agrária, no dia 26 de janeiro de 1975 efetua-se a 2 ${ }^{\mathrm{a}}$ Assembleia de Delegados do Sindicato dos Trabalhadores Agrícolas do Distrito de Beja, na capital do Baixo Alentejo, sul de Portugal, onde são aprovadas duas resoluções que marcam de forma decisiva toda a estratégia de luta futura dos trabalhadores agrícolas dos campos do sul. Numa das resoluções, pela primeira vez, os assalariados rurais votam a exigência imediata da expropriação do latifúndio e a realização da reforma agrária e na outra aprovam a ida dos trabalhadores desempregados para as explorações agrícolas subaproveitadas, dandose aí início, quer os patrões quisessem ou não, aos trabalhos agrícolas necessários ao aumento da produção ${ }^{4}$.

Em simultâneo com esta radicalização da luta dos assalariados rurais, e influenciado por ela, o Partido Socialista (PS) faz críticas

\footnotetext{
O PCP sempre apresentou este acontecimento como a primeira ocupação de terras nos campo do sul, datando daqui o início da reforma agrária: Sobre esta questão ver, entre outros, os seguintes documentos: a) Relatório da comissão concelhia de Beja de colocação de trabalhadores, de 29/11/74 - Arquivo do Sindicato dos Trabalhadores Agrícolas (STA) do distrito de Beja; b) Acta no 5 da comissão distrital de Beja de distribuição de trabalhadores, de 4/12/74 - Arquivo do STA do distrito de Beja; c) A Capital, de 21/12/74; d) Diário de Notícias, de 23/01/74; e) Diário do Governo (DG), II série, de 15/2/75.

${ }^{4}$ Cf. Diário do Alentejo, de 28/01/1975.
} 
à política da Secretaria de Estado da Agricultura, defendendo uma reforma agrária assente na expropriação dos latifúndios e das grandes propriedades situadas nos perímetros de rega construídos pelo Estado ${ }^{5}$. O Partido Comunista Português (PCP) reformula a sua proposta de reforma agrária, a qual, a partir da I Conferência dos Trabalhadores Agrícolas do Sul, realizada na cidade de Évora, em 9 de fevereiro de 1975, passa a concretizar-se na luta pelo pleno emprego 6 . O Movimento das Forças Armadas (MFA), que vem defendendo a "dinamização da agricultura" e a "reforma gradual da estrutura fundiária", passa a advogar, em janeiro de 1975, uma reforma agrária que elimine o latifúndio e limite as grandes explorações agrícolas capitalistas ${ }^{7}$. E o Partido Popular Democrático (PPD), cujas posições são idênticas às da ALA, continua, à semelhança desta organização, defendendo a reconversão capitalista dos campos, cujas margens de afirmação vão-se tornando cada vez mais estreitas, o que conduz ao declínio progressivo desta estrutura associativa a partir do ano de $1975^{\circ}$.

\section{O movimento de ocupação de terras nos campos do sul. O 11 de março de 1975 e a nova política agrária}

É num quadro social onde, nos campos do sul, as reivindicações dos assalariados rurais se confundem com a defesa da expropriação da grande propriedade e a realização da reforma agrária, e os principais partidos, bem como o MFA, surgem a propor reformas profundas na estrutura fundiária existente a sul de Portugal, que se dá o falhado golpe de direita, em 11 de março de 1975, do qual resulta um reforço dos setores de esquerda ao nível do aparelho político-militar do país. Essa mudança política vai reforçar o movimento de conflitualidade social nos campos.

Em 26 de março toma posse o IV Governo Provisório, chefiado por Vasco Gonçalves, tendo como ministro da Agricultura Fernando Oliveira Baptista. Na reunião de Conselho de Ministros de 15 de abril são aprovadas "as bases gerais dos programas de medidas económicas de emergência". No seu anexo 3 prevê-se um conjunto de medidas destinadas a concretizar a reforma agrária a curto prazo, entre as quais se destacam a

\footnotetext{
5 Cf. A Capital, de 10/01/1975.

${ }^{6}$ Cf. Conclusões da I Conferência dos Trabalhadores Agrícolas do Sul promovida pelo PCP, in Diário do Alentejo, 13/02/1975.

7 Cf. Boletim Informativo das Forças Armadas, 26/11/1974.

8 Cf. Diário do Alentejo, 11/06/1975.
} 
"nacionalização global dos prédios rústicos que, no todo ou em parte, se situem nos perímetros dos aproveitamentos hidroagrícolas levados a efeito com investimentos públicos, pertencentes a indivíduos ou sociedades que sejam proprietários, no conjunto dos perímetros, de uma área superior a 50 ha de terra", a "expropriação das propriedades de sequeiro de área superior a 500 ha", a "criação de um sistema de crédito agrícola de emergência, pessoal e em natureza, para satisfazer as necessidades dos pequenos e médios agricultores" e a "restituição dos baldios aos seus legítimos utentes".

Tendo por guia as orientações contidas no anexo 3 das "bases gerais", o Ministério da Agricultura chama a si a tarefa de concretizar a reforma agrária. Atua em dois vetores: apoiar os pequenos e médios agricultores e intervir nas relações de propriedade com vista à liquidação do latifúndio. Quanto ao primeiro aspecto, para além da divulgação do aumento dos preços dos produtos agrícolas a pagar ao produtor e da garantia da respectiva comercialização, é criada um linha de crédito no montante global de cinco milhões de contos (vinte e cinco milhões de euros, hoje) destinada aos pequenos e médios produtores que dela quisessem usufruir para a aquisição de adubos, rações, fertilizantes, etc. ${ }^{10}$. No que diz respeito à intervenção nas propriedades agrícolas da zona do latifúndio, são anunciadas para breve medidas legislativas visando a nacionalização dos prédios rústicos nos perímetros de rega e a expropriação das terras de sequeiro, cuja concretização, segundo palavras de Fernando Oliveira Baptista, será sempre feita em diálogo com trabalhadores agrícolas e pequenos e médios agricultores no quadro dos Conselhos Regionais de Reforma Agrária a criar ${ }^{11}$.

No desenvolvimento desta agenda de intenções constituem-se os Conselhos Regionais de Reforma Agrária ${ }^{12}$ e criam-se, por despacho ministerial, os Centros Regionais de Reforma Agrária (CRRA) ${ }^{13}$.

Perante este assumir, por parte do IV Governo Provisório, duma política orientada para a concretização da reforma agrária, os

\footnotetext{
${ }^{9}$ Cf. Decreto-lei no 203-C/75, de 15 de abril.

${ }^{10} \mathrm{Cf}$. Decreto-lei no $251 / 75$, de 23 de maio.

${ }^{11}$ Cf. A Capital, 07/05/1975.

12 Os Conselhos Regionais de Reforma Agrária, onde tinham assento, para além de representantes do poder político- militar, os delegados dos assalariados rurais e dos pequenos proprietários, são criados pelo DL no $351 / 75$ de 5 de maio.

${ }^{13}$ O Centro Regional de Reforma Agrária de Beja é constituído por despacho do ministro Fernando Oliveira Baptista, de 19/05/75. Os restantes Centros (Setúbal, Portalegre, Évora, Santarém, Faro e Lisboa) formam-se por despachos do mesmo ministro no período compreendido entre 5 de junho (Setúbal) e 10 de setembro (Lisboa) de 1975.
} 
sindicatos dos trabalhadores agrícolas dos campos do sul endossam esta responsabilidade para o Estado e, numa atitude de cooperação com o poder, travam mesmo algumas tentativas de ocupações de terras que vão surgindo em resultado da pressão exercida pelos trabalhadores temporários com o intuito de verem resolvida a sua situação de desemprego.

Embora defendendo uma reforma agrária feita com ordem e sob o controle dos Conselhos Regionais de Reforma Agrária, os sindicatos rurais, não podendo aguentar por mais tempo o movimento social dos assalariados rurais em expectativa, pressionam, por sua vez, o governo no sentido deste avançar na concretização das medidas de reforma agrária anunciadas. Nas zonas onde a organização sindical é mais débil, portanto onde o controle do PCP não é tão vincado sobre os trabalhadores do campo, por todo o inverno e primavera de 1975 desenvolvem-se várias ocupações de terras protagonizadas por pequenos e médios produtores, também alugadores de maquinaria agrícola, que, tendo dívidas a bancos em virtude do investimento feito, precisam de ter as máquinas a trabalhar ${ }^{14}$.

No início do mês de junho a situação nos campos do sul parece clara. Ou o governo legisla em matéria de reforma agrária e intervém nas relações de propriedade ou os trabalhadores agrícolas avançam de forma mais intensa e generalizada para as ocupações.

Como o mês de junho de 1975 passa sem que as medidas anunciadas sejam promulgadas, por divergências entre as forças políticas que compõem o IV Governo Provisório (onde sobressaem as reservas colocadas pelo PS), o movimento de ocupações de terras começa a desenvolver-se na zona de grande propriedade situada no sul de Portugal.

\section{As ocupações de terras na Zona de Intervenção da Reforma Agrária (ZIRA)}

Um grupo de trabalhadores rurais da freguesia do Cabeção, em maio de 1975, concelho de Mora, Alentejo, é entrevistado para o telejornal,

\footnotetext{
${ }^{14}$ As ocupações que ocorrem a 3 de fevereiro de 1975, no distrito de Évora, inserem-se no âmbito do que se refere. Neste dia um grupo de pequenos agricultores dirige-se à herdade do Pombal, perto de Évora, do Duque de Cadaval e ocupa as instalações. O mesmo fazem pequenos agricultores das Alcáçovas e Vendas Novas (distrito de Évora). Os primeiros ocupam a herdade Entre-as-Matas, de João Branco Núncio, e os segundos a herdade da Chaminé. Cf. Diário do Alentejo, de 05/02/75.
} 
no âmbito de uma campanha do Instituto de Reorganização Agrária (IRA) ${ }^{15}$ :

Jornalista: "Mas, ao que consta, essa ocupação também seria motivada por um certo abandona e desleixo...

Trabalhador rural: Uma foi causada por causa dos trabalhadores andarem lá e ele não pagar, e outra foi por andar abandonada. Praticamente abandonada!"16.

O trabalhador admite que as ocupações poderiam ter sido feitas com mais calma, "ver o que lá está", quem "vai para lá trabalhar", formar uma "comissão de trabalhadores para justificar quais as propriedades que devem ser ocupadas".

Em junho de 1975 uma reportagem da televisão pública portuguesa foi conhecer a ocupação da Quinta da Vargem, em Unhais da Serra, concelho da Covilhã. Nada se sabe do "patrão", "está ausente... o irmão estava implicado no 11 de março, não se sabe se está em Madrid, se no Brasil".

A quinta tinha 5.000 hectares, 2/3 pinhal. 75.000 macieiras, que produzem 500 toneladas de maçã por ano, 15.000 pessegueiros e 2.500 cerejeiras, tem barragem própria, terrenos para caça e, conta um dos ocupantes, "é atravessada por uma ribeira onde a senhora Garret (mulher do proprietário) e os seus amigos se entretinham a pescar nas horas de ócio".

O jornalista vai entrevistar um pastor da quinta. Vestido com trajes típicos, um grande capote, o pastor diz que "nunca teve na vida um dia de descanso", regressa sempre ao pôr do sol para comer, e "dorme ao pé do gado".

Jornalista: "Qual era o seu ordenado quando estava cá o Garret?

- Era 2 contos e quinhentos.

- E depois?

- Depois passou a 6 contos e seiscentos com garantias.

- Garantias?

- Sim, a casa, 5 litros de azeite e um bocado de terra para amanhar.

- Quem é que vos paga agora sem patrão?

- É a comissão de trabalhadores"17.

Estes são dois exemplos de centenas que ocorrem e são paradigmáticos do processo.

\footnotetext{
${ }^{15}$ O IRA é criado pelo DL no 539/74, de 12 de outubro, no âmbito da reestruturação da Secretaria de Estado da Agricultura do III Governo Provisório, enquanto instrumento ao serviço duma política agrária visando o aumento da produtividade assente na reconversão capitalista da agricultura portuguesa.

${ }^{16}$ RTP Noticiário Nacional, 27 de maio de 1975, Arquivo da RTP.

${ }^{17}$ Ocupação da Quinta da Vargem, RTP Noticiário Nacional, 24 de junho de 1975, Arquivo da RTP.
} 
É este movimento de ocupações de terras que, ao instituir a reforma agrária no terreno, impondo-a ao poder político-militar, garante a sua sobrevivência no período subsequente ao golpe militar de 25 de novembro de 1975. De fato, na contenção negociada do processo revolucionário entre o PCP e o MFA, que o 25 de novembro representa, a reforma agrária não é desarticulada, ficando antes, por decisão do VI Governo Provisório, circunscrita ao território das ocupações, o qual passa a ser designado por Zona de Intervenção da Reforma Agrária (ZIRA). Do ponto de vista geográfico este território abrange os distritos de Beja, Évora e Portalegre, os concelhos do sul do distrito de Setúbal, os concelhos de Idanha-a-Nova e Vila Velha de Ródão do distrito de Castelo Branco, os concelhos de Vila Franca de Xira e Azambuja do distrito de Lisboa, onze concelhos do distrito de Santarém e treze freguesias do distrito de Faro (Fig. 1).

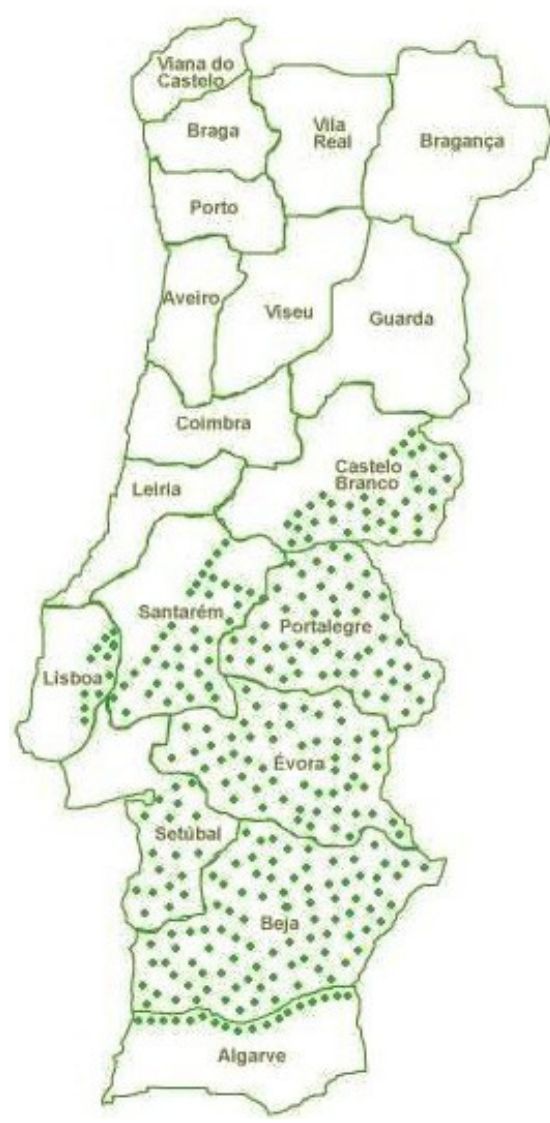

Fig. 1. Portugal Continental (Constantino Piçarra) 
Neste processo de ocupações de terras, caracterizamos três fases distintas, o que fazemos tendo em consideração o que a pesquisa empírica nos mostra. E o que ela revela é que, ao contrário do que António Barreto defende, a reforma grária não partiu do Estado para a sociedade (BARRETO, 1987, p. 151-152), mas sim o inverso. Também não é, como diz, que um dos traços dominantes do processo de reforma agrária está associado a uma revolução feita através do Estado e das instituições (BARRETO, 1983, p. 550). Este olhar sobre a reforma agrária não toma em consideração a contextualização em que o processo de ocupações se desenrola, nomeadamente o movimento reivindicativo pela garantia de emprego que o antecede. De fato, foi a luta em torno das primeiras convenções de trabalho, dos primeiros contratos coletivos por distrito e da aplicação das suas cláusulas sobre garantia de emprego que forjou um poderoso movimento social de assalariados rurais, o qual anexou às reivindicações iniciais a expropriação da grande propriedade como condição indispensável à materialização dos objetivos porque se lutava.

\section{Primeira fase de ocupações (até 31/07/1975)}

Esta primeira fase de ocupações, que vai até final do mês de julho de 1975, circunscrita praticamente aos três distritos do Alentejo (Beja, Évora e Portalegre), não adquire, de fato, grande amplitude, representando apenas 13,5\% (156353 hectares) do total das terras tomadas pelos trabalhadores ao longo do ano (Quadro 1). Não é fácil determinar, com rigor, o início desta fase de ocupações onde as intervenções do Estado sobre explorações agrícolas totalmente ou parcialmente abandonadas, ao abrigo do DL n 660/74, se confundem com ocupações de terras. São iniciativas desencadeadas pelos trabalhadores agrícolas temporários nas situações em que sobre eles pende grande ameaça de desemprego ou onde os assalariados rurais já se encontram há muito tempo sem receber qualquer salário, de que é exemplo o distrito de Beja, ou ainda nos casos em que a sabotagem económica praticada pelos proprietários ameaça a viabilidade das explorações agrícolas.

Num clima de crescente tensão entre assalariados rurais e empresários agrícolas, as ocupações desta fase não podem ser desenquadradas de um contexto em que ao anúncio, por parte do IV Governo Provisório (março a julho de 1975), de medidas de concretização de reforma agrária, se sucede o seu protelamento, motivado por divergências existentes 
entre os partidos que compõem o governo ${ }^{18}$. $\mathrm{O}$ adiar da promulgação da legislação anunciada pelo Estado, conducente à concretização da reforma agrária - as leis de expropriação e nacionalização das grandes propriedades do sul -, conduz também às ocupações de terras desta fase, cumprindo-se, assim, um dos objetivos do movimento dos trabalhadores agrícolas: pressionar o Estado a instituir a reforma agrária, tal como vem sendo divulgada.

Portanto, é sob pressão do movimento social dos assalariados rurais, traduzido na tomada de herdades, que, em 4 de Julho de 1975, numa reunião do Conselho de Ministros do IV Governo Provisório, são aprovadas as leis da reforma agrária: o DL no 406-A/75, que fixa as normas a que devem obedecer a expropriação dos prédios rústicos, o DL no 407-A/75, que nacionaliza as terras beneficiadas pelos aproveitamentos hidroagrícolas, o DL no 406-B/75, que estabelece os requisitos necessários para que o Estado reconheça as novas unidades de produção da reforma agrária, condição para poderem aceder a apoio técnico e a crédito, o DL no 407-C/75, que põe fim às coutadas, com excepção das turísticas, e o DL no $407-B / 75$, que coloca sob o controle do Estado toda a produção de cortiça amadia extraída ou a extrair na campanha de 1975 .

Quadro 1. Movimento de ocupações de terras nos campos do sul, em 1975

\begin{tabular}{|c|c|c|c|c|c|}
\hline $\begin{array}{c}\text { Fases do } \\
\text { movimento de } \\
\text { Ocupações }\end{array}$ & $\begin{array}{c}\text { Beja }^{(\mathbf{l})} \\
\text { Área (ha) }\end{array}$ & $\begin{array}{l}\text { Évora }^{(2)} \\
\text { Área (ha) }\end{array}$ & $\begin{array}{c}\text { Portalegre }^{(2)} \\
\text { Área (ha) }\end{array}$ & $\begin{array}{c}\text { Alentejo } \\
\text { Total } \\
\text { Área (ha) }\end{array}$ & $\begin{array}{c}\text { ZIRA }^{(2)} \\
\text { Área (ha) }\end{array}$ \\
\hline $\begin{array}{l}1 \text { a fase } \\
\text { até } 31 / 07 / 75\end{array}$ & 30.783 & 53.461 & 40.144 & $\begin{array}{l}124.388 \\
(12,7 \%)\end{array}$ & $\begin{array}{l}156.353 \\
(13,5 \%)\end{array}$ \\
\hline $\begin{array}{l}2 \text { a fase } \\
\text { de } 01 / 08 / 75 \text { a } \\
30 / 09 / 75\end{array}$ & 53.915 & 213.098 & 9.910 & $\begin{array}{l}276.923 \\
(28,1 \%)\end{array}$ & $\begin{array}{l}309.338 \\
(26,6 \%)\end{array}$ \\
\hline $\begin{array}{l}3^{a} \text { fase } \\
\text { de } 01 / 10 / 75 \text { a } \\
31 / 12 / 75\end{array}$ & 233.420 & 164.232 & 183.857 & $\begin{array}{l}581.509 \\
(59,2 \%)\end{array}$ & $\begin{array}{l}696.743 \\
(59.9 \%)\end{array}$ \\
\hline Total & 318.118 & 430.791 & 233.911 & $\begin{array}{l}982.820 \\
(100 \%)\end{array}$ & $\begin{array}{c}1.162 .434 \\
(100 \%)\end{array}$ \\
\hline
\end{tabular}

(1) PIÇARRA, 2008.

(2) BARROS, 1986.

\footnotetext{
${ }^{18}$ O IV Governo Provisório é um governo de coligação onde estão representados o PCP, o PS, o PPD e o Movimento Democrático Português/Centro Democrático Eleitoral (MDP/CDE). Nesta fase da revolução, de transição para o socialismo, enquanto o PCP desenvolve uma estratégia de aproximação ao poder, de forma ordeira, através duma "política de entrismo", o PS, no campo oposto, liderando uma vasta fronda onde se encontram as forças de direita, combate esta política e esta ação.
} 


\section{Segunda fase de ocupações (de 01/08/1975 a 30/09/1975)}

No início de agosto de 1975 a situação que se vive nos campos do sul pode ser caracterizada da seguinte maneira:

Por um lado, existe um decreto-lei aprovado em Conselho de Ministros (DL no 406-A/75), embora só transcrito no Diário do Governo a 11 de agosto, que diz que estão sujeitos a expropriação os prédios rústicos que:

a) Pertençam a pessoas singulares, sociedades ou pessoas colectivas de direito privado, ainda que de utilidade pública, que sejam proprietárias, no território nacional, de prédios rústicos que, no seu conjunto (...) se verifique corresponderem a mais de 50000 pontos ou, independentemente desse requisito, ultrapassarem a área de 700 hectares; b) Pertençam a pessoas singulares, sociedades ou pessoas colectivas de direito privado, ainda que de utilidade pública, que tenham incorrido em qualquer das situações previstas, como fundamento de intervenção, no Decreto-lei no 660/74, de 25 de Novembro, e legislação complementar; c) Estejam incultos ou não alcancem os níveis mínimos de aproveitamento estabelecidos e a estabelecer por portaria do Ministério da Agricultura e Pescas.

A pontuação de cada exploração agrícola é determinada por uma tabela anexa ao DL no $406-\mathrm{A} / 75$ onde a cada hectare de terra é atribuído um determinado número de pontos em função do tipo de culturas e da qualidade dos solos.

Por outro lado, os responsáveis diretos das explorações agrícolas alvo de expropriação iniciam nuns casos, e aprofundam noutros, o processo de descapitalização dessas explorações, pela razão óbvia de saberem que elas vão mudar de proprietário. Neste contexto, a demora em expropriar estes prédios rústicos não só está a trazer enormes prejuízos à economia nacional, como se traduz em aumento de desemprego para os assalariados rurais. Esta situação faz que muitos trabalhadores, naturalmente receosos em relação a participarem no movimento de ocupações, se mostrem, neste quadro, disponíveis para se envolverem nestas ações. A esta realidade outra se junta e que é a da existência do decreto-lei que prevê a expropriação da grande propriedade. Assim, as ocupações nesta fase surgem aos olhos dos trabalhadores como uma espécie da aplicação da lei por antecipação. Está-se, portanto, perante ocupações de cariz marcadamente político, no sentido em que são dirigidas e controladas pelos sindicatos agrícolas e onde nos três 
distritos do Alentejo são ocupados 276.923 hectares de terra, 28,1\% do total das ocupações ocorridas neste território no ano de 1975 (Quadro 1).

É preciso, no entanto, notar que as ocupações nesta fase não se desenvolvem sempre ao mesmo ritmo. Embora se vão ampliando à medida que o mês de julho vai decorrendo, o período mais intenso situa-se entre finais de julho e 11 de agosto de 1975, data em que surgem publicados em Diário do Governo os decretos-lei sobre nacionalizações e expropriações de terras, intervalo de tempo que corresponde à luta fortíssima que se trava no seio do MFA pelo controle da situação políco-militar do país entre o Grupo dos Nove, aliado do PS, e a facção gonçalvista, ligada ao PCP, da qual resulta a vitória desta última, o que origina a formação do V Governo Provisório, que toma posse em 8 de agosto de 1975.

É ainda nesta fase que o Estado, através dos CRRA, desenvolve um esforço significativo de coordenação e ajuda aos assalariados rurais na gestão das novas unidades de produção - Unidades Coletivas de Produção (UCP) e cooperativas -, que se vão constituindo a partir do movimento de ocupações de terras. Esta ajuda, concretizada, no essencial, em apoio técnico prestado pelo Ministério da Agricultura, não é, contudo, vista como suficiente pelos sindicatos agrícolas, que reclamam linhas de crédito, nomeadamente para o pagamento dos salários dos trabalhadores integrados nestas novas unidades de produção. Em resposta a estas reivindicações, o Estado disponibiliza crédito, não para pagamento de salários, mas para a aquisição de meios de produção, e cria uma dotação orçamental, gerida pelos CRRA, com o objetivo de financiar as herdades geridas coletivamente pelos trabalhadores onde a continuação do processo produtivo está em causa por falta de capital ${ }^{19}$.

Em 6 de setembro de 1975 cai o V Governo Provisório, a que se segue o VI Governo, que toma posse em 19 do mesmo mês, liderado pelo almirante Pinheiro de Azevedo. Nesta conjuntura os sindicatos agrícolas reforçam a pressão do movimento social dos assalariados rurais junto do governo, reivindicando apoio financeiro para as novas unidades de produção, especialmente para pagamento de salários. Deste braço de ferro entre sindicatos e governo resulta a promulgação do Decreto-lei no 541-B/75, de 27 de setembro, que elimina dificuldades de acesso ao crédito por parte de UCP e cooperativas, e, em 29 de setembro,

${ }^{19}$ Cf. Despacho do secretário de Estado da Estruturação Agrária de 7 de agosto de 1975. DG, II série, de 20/08/75 (Suplemento). 
por despacho do secretário de Estado da Estruturação Agrária, António Bica, o crédito agrícola de emergência alarga-se a explorações agrícolas geridas pelos trabalhadores, podendo ser utilizado para o pagamento de salários.

Dois dias depois, em 1 de outubro de 1975, inicia-se a terceira e última fase de ocupações de terras nos campos do sul.

\section{Terceira fase de ocupações (de 01/10/1975 a 31/12/1975)}

Garantido o crédito para o pagamento dos salários dos trabalhadores das novas unidades de produção, de outubro até final do ano de 1975, com o momento de apogeu em outubro, passam para controlo dos assalariados rurais 693.743 hectares de terra, o que representa $59,9 \%$ do total das ocupações realizadas em 1975 (Quadro 1).

$\mathrm{Na}$ explicação da amplitude das ocupações desta fase encontrase, sem dúvida, a possibilidade criada pelo VI Governo Provisório de utilização das verbas do crédito agrícola de emergência para o pagamento de salários dos trabalhadores das herdades coletivas. No entanto, a esta razão outras se juntam.

Outubro é o mês das sementeiras. A não realização desta tarefa agrícola coloca gravíssimos problemas de desemprego não só durante o outono/inverno de 1975, mas também na primavera/verão do ano seguinte. Como os empresários, sobre quem pende o decreto-lei das expropriações, não se mostram disponíveis para efetuarem as sementeiras, os assalariados rurais, com o objetivo de garantirem os postos de trabalho, avançam para as ocupações num movimento concertado pelos sindicatos agrícolas.

Por outro lado, parece evidente para as organizações dos trabalhadores agrícolas que a constituição do VI Governo Provisório representa um governo onde a esquerda tem um peso menor. A formação do governo chefiado pelo almirante Pinheiro de Azevedo e as movimentações no interior do MFA fazem prever, no início de outubro de 1975, a possibilidade real duma ruptura no processo revolucionário, com todas as implicações daí decorrentes no retrocesso da reforma agrária tal como vinha sendo desenvolvida pelos IV e V Governos Provisórios. Sintoma deste novo rumo é a publicação do Decreto-lei n. ${ }^{\circ} 588 / 75$, de 21 de outubro, que abre a possibilidade de indivíduos implicados com o Estado Novo poderem ser eleitos para as direções das cooperativas agrícolas, o que irá culminar, em 1976, portanto já depois do 25 de novembro de 1975, na substituição das chefias dos CRRA e 
na publicação do Decreto-lei no 236-A/76, de 5 de abril, que elimina a sabotagem econômica como fundamento para as expropriações e alarga a todos os proprietários o direito de reserva.

Esta nova situação política, a partir de outubro, empurra os sindicatos agrícolas para um trabalho de reorganização das herdades controladas pelos trabalhadores, agrupando-as em UCP. A amplitude atingida pelas ocupações de terras durante o mês de outubro dá origem à tomada pelos trabalhadores de explorações agrícolas de alguns pequenos e médios proprietários que tinham entrado em litígio com as comissões locais dos sindicatos por terem sido alvo de distribuição de trabalhadores, com isto sendo sobrecarregados com salários que não podiam pagar. Por outro lado, ainda durante esta terceira fase de ocupações, passam para o controlo dos trabalhadores, herdades que se encontram arrendadas a pequenos rendeiros e seareiros.

A ocupação de terras de alguns destes pequenos e médios proprietários, aliada à posição defendida pela gestão das novas unidades de produção e que é a da integração destes pequenos rendeiros ou seareiros como assalariados rurais, faz com que estes pequenos e médios produtores olhem o futuro com apreensão, fato que ao ser ampliado pelo bloco conservador, constituído por todos os opositores às transformações nos campos do sul, origina o medo nos pequenos. Esta vai ser uma base de apoio do PS e dos grandes proprietários para chamarem a si as classes intermédias da sociedade rural do sul do país.

A concentração, em Beja, de cerca de dois mil pequenos agricultores, em 24 de outubro de 1975, enquadrada por militantes do PS, exemplifica bem este divórcio, cada vez mais cavado, entre a reforma agrária, tal como vai sendo concretizada pelas UCP, e os pequenos e médios agricultores $^{20}$. É esta realidade que possibilita base social de apoio nos campos do sul à concretização de diversas medidas legislativas de desarticulação da reforma agrária protagonizadas depois mais tarde pelo VI Governo Provisório e, de seguida, pelo I Governo Constitucional.

\section{O PCP e a Reforma Agrária: uma nova perspectiva}

O Partido Comunista Português foi o partido dominante nos campos do Alentejo e do Ribatejo. Embora Barreto, citando o estudo de José Pacheco Pereira, Os Conflitos Sociais nos Campos do Sul de Portugal (1983), defenda que o PCP estava a recuar em influência militante no

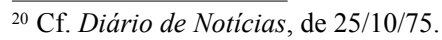


Alentejo quando se dá o 25 de abril (BARRETO, 1987, p. 178), é um fato que a extrema-esquerda ou o PS nunca conseguiram contrabalançar a influência do PCP, durante a revolução, no sul como conseguiram nas cinturas industriais ou no setor dos serviços dos grandes centros urbanos. António Barreto (BARRETO, 1984, p. 43) aponta as razões por que o PCP superou a concorrência política nos campos do sul: capacidade de organização, linguagem e recrutamento classistas, predominância do proletariado rural na região, funcionários permanentes, colaboração do MFA, apoio do Ministério da Agricultura e do Ministério do Trabalho e a implantação antiga e tradicional do PCP. A população agrícola diminui consideravelmente durante a década de 60 , fruto da emigração e da industrialização, mas estavam bem vivos na memória dos assalariados agrícolas os duríssimos tempos, até à década de 50, em que havia um desemprego crónico (emprego sazonal) e o PCP era o único partido oposicionista, numa área em que predominava o grande latifúndio $(5 \%$ das explorações agrícolas possuem 85\% da terra) (BARRETO, 1984, p. 45). Os assalariados agrícolas são uma reserva estratégica de militância do PCP, fosse porque são um seu bastião histórico (mais de 40 anos de resistência na clandestinidade), fosse porque a industrialização dos anos 60 do século XX tinha imposto a ida de muitos destes assalariados para as cinturas industriais das cidades, como proletários industriais, que aí mantinham a tradição, a ligação e a reprodução do partido.

Importa referir porém que ao contrário do que a própria memória do Partido teceu quer as nacionalizações de alguns setores estratégicos quer a reforma agrária só serão uma bandeira permanente do PCP a partir de fevereiro de 1975.

No verão de 1974 a questão agrária não é central. Há referências à defesa da abolição dos foros e apoio em crédito aos pequenos e médios camponeses. Generaliza-se, logo em maio de 1974, a política de constituir rapidamente sindicatos, que dão uma unidade e expressão orgânica às reivindicações dos assalariados rurais. Os sindicatos estão já no terreno a partir de junho de 1974 e têm um papel na gestão da mãode-obra nas grandes explorações agrícolas. A principal reivindicação é, como referimos, a luta pelo contrato coletivo de trabalho.

Em 29 de dezembro de 1974 reúne-se a I Conferência de Camponeses do Norte, onde outras medidas são defendidas, como o reconhecimento dos baldios como propriedade coletiva inalienável; a urgente criação de um sindicato de assalariados agrícolas do norte e uma extensa política de proteção social dos assalariados agrícolas. Exige Álvaro Cunhal, no discurso de abertura da conferência de camponeses do norte, que se 
crie legislação que regulamente o trabalho dos assalariados agrícolas, nomeadamente no que diz respeito aos horários, salários, instalações dignas para trabalhadores deslocados, etc.

O PCP reúne-se de novo no Congresso de outubro de 1974, e a Plataforma de Emergência, o programa aprovado no Congresso, centra-se em medidas de resolução do problema agrário que protelam a expropriação de terras. Defende a requisição pelo Estado das terras agrícolas e a sua entrega a formas de gestão pública, cooperativas ou explorações familiares; a abolição dos foros; créditos, seguros e assistência técnica aos pequenos e médios agricultores; uma nova política de preços; preços diferenciados em escala regressiva (para o trigo e o vinho, por exemplo) e preços garantidos do leite, da carne. Uma política de importações subordinada aos interesses económicos de Portugal; liquidação da organização cooperativa da lavoura, com uma política de extinção dos grêmios da lavoura; forte tributação aos grandes proprietários e rendeiros absentistas ${ }^{21}$.

Até aos primeiros dois meses de 1975 a política do PCP é a de intervencionar a terra, no sentido do seu correto aproveitamento, mas sem questionar a propriedade dessa terra. Nisto, não se distinguiu da política dos restantes membros do governo, uma vez que também o governo tinha colocado em prática medidas, como observa Oliveira Baptista, "que ligavam o direito a explorar a terra (e não a sua propriedade!) ao seu conveniente aproveitamento" (BAPTISTA, 1978, p. 9). Mas em fevereiro, na I Conferência de Trabalhadores Agrícolas do Sul, realizada em Évora, o partido assume decisivamente a luta pela reforma agrária e a defesa da ocupação de terras, com a seguinte orientação: "As terras obtidas (...) devem ser entregues a Sindicatos de Trabalhadores Agrícolas ou Ligas de Pequenos Agricultores, que explorarão em regime de cooperativa de produção, ou então deverão ser exploradas directamente pelo Estado" "22. Nesta conferência, Cunhal propõe ainda outras medidas importantes: a consolidação dos sindicatos e das ligas, que têm para além da reforma agrária um papel central no recrutamento para o partido, mas também nos recursos financeiros deste. O PCP tem nos sindicatos agrícolas uma política mais radical que nos centros urbanos. A direção reconhece, por exemplo, que há uma burocratização das direções de alguns destes sindicatos e Cunhal

21 "7o Congresso (Extraordinário) do PCP". Documentos Politicos do PCP. Série Especial. Lisboa: Avante!, 1974, p. 294-295.

22 "I Conferência de Trabalhadores Agrícolas do Sul, 9 de fevereiro de 1975". In: O PCP e a Luta pela Reforma Agrária. Cadernos do PCP 7. Lisboa: Edições Avante!, 1975, p. 154. 
propõe mesmo que nesses casos devem ser expulsos aqueles que façam acordos com os grandes agrários; propõe ainda que os trabalhadores sejam distribuídos pelas terras conforme os hectares de terra, iniciando uma política assente na garantia de emprego. Finalmente, a conferência propõe a nacionalização da banca ${ }^{23}$.

Começava a luta do PCP contra os grandes proprietários de terras, reunidos sobretudo em torno da ALA (mais tarde reorganizada na Confederação dos Agricultores de Portugal (CAP). O líder do PCP discursa no fim da Conferência em Évora, recuperando a reforma agrária, uma bandeira histórica dos comunistas desde a segunda metade da década de 40 do século XX. Com uma novidade face a Rumo à Vitória, que é o enquadramento da reforma agrária na nova estrutura de alianças defendida pelo partido. Assim, a reforma agrária passa a ser uma bandeira erguida no quadro da estratégica "Aliança-Povo MFA":

Em todos os debates desta Conferência um facto foi salientado: que há terras imensas para cultivar por um lado e que há milhares de braços sem trabalhar por outro. (...) A reforma agrária surge natural como a própria vida. Pelas mãos dos trabalhadores, a Reforma Agrária deu os primeiros passos. Se soubermos reforçar a organização e a unidade dos trabalhadores, se soubermos reforçar a aliança Povo-Forças Armadas, o desenvolvimento da reforma agrária é irreversível (CUNHAL, 1975, p. 85-86).

Em 16 de abril de 1975, em Beja e em Évora, mais de 20.000 trabalhadores agrícolas manifestam-se sob a palavra de ordem "Queremos a Reforma Agrária!", exigindo a expropriação dos latifúndios sem indemnização (BARRETO, 1984, p. 55). O IV Governo Provisório, em 4 de julho de 1975, aprova, com ausência do PS, as leis da reforma agrária, mas adia a sua publicação, que só se vai concretizar já no V Governo, em 11 de agosto de 1975.

Durante o IV Governo constitui-se um Ministério da Agricultura que será dirigido por um homem próximo do PCP, Oliveira Baptista, ministro dos IV e V Governos Provisórios. Para evitar as ocupações selvagens - que o PCP condena - o partido apoia a criação dos centros e conselhos regionais da reforma agrária, em dependência do Ministério. Os sindicatos têm um papel de estreita ligação ao aparelho de Estado. Barreto fala mesmo de "osmose" (BARRETO, 1984, p. 72): 
A 'osmose' oficial dos sindicatos (...) Mas é nas instituições propriamente ditas que mais se revela o poder 'oficial' dos sindicatos. Estes ficaram ligados às comissões técnicas concelhias, às Comissões Distritais Rurais (CDRs) e aos Conselhos Regionais da Reforma Agrária, tendo tido larguíssima influência (1975) nos Centros Regionais de Reforma Agrária (BARRETO, 1984, p. 72).

No mês de julho de 1975 são organizadas pelo PCP dezenas de conferências e encontros de trabalho com trabalhadores e camponeses com o intuito de organizar o movimento social. As orientações de $O$ Militante não são declarações de intenções, propaganda vaga, mas guias de ação prática para uma organização de grande dimensão. Só em julho de 1975, para além de todo o esforço que dedica ao Congresso dos Sindicatos, o PCP vai organizar milhares de trabalhadores em encontros como a Conferência Unitária de Metalúrgicos do Porto ${ }^{24}$, a Conferência de Trabalhadores das Empresas Nacionalizadas ${ }^{25}$, a Conferência Unitária dos Trabalhadores Têxteis ${ }^{26}$, a I Conferência Unitária de Corticeiros do Centro e do $\mathrm{Sul}^{27}$. Estes grandes encontros são feitos em paralelo com um esforço para dirigir as comissões de trabalhadores e moradores ${ }^{28}$, as assembleias populares, bem como enquadrar todo o processo de efetivação da reforma agrária.

Tratava-se por isso de terminar com o V Governo, sofrendo o menor dano possível para o PCP. O menor dano possível incluía, nesta altura do processo revolucionário, assegurar influência no VI Governo, dirigir de forma controlada a mobilização social que existia para garantir que na sua passagem a um regime democrático podiam manter-se as nacionalizações, concretizar a reforma agrária e garantir a independência de Angola, sob direção do MPLA.

A partir do V Governo, e à medida que crescem as ocupações, a política do PCP é tentar agrupar todas as terras ocupadas (em geral os trabalhadores ocupavam as terras onde trabalhavam) em grandes unidades coletivas de produção. O PCP abandona definitivamente a

24 "Conferência Unitária de metalúrgicos do distrito do Porto". In: Avante!, Série VII, 10 de julho de 1975 , p. 5.

25 "Conferência de trabalhadores das empresas nacionalizadas". In: Avante!, Série VII, 10 de julho de 1975 , p. 5.

26 "A Indústria têxtil ao serviço dos trabalhadores e do povo". In: Avante!, Série VII, 10 de julho de 1975 , p. 5.

27 "Corticeiros do centro e do sul na sua I Conferência Unitária". In: Avante!, Série VII, 31 de julho de 1975, p. 9

28 “Comissões de Moradores na Defesa das populações!". In: Avante!, Série VII, 10 de julho de 1975 , p. 4. 
política de dividir a terra por quem a trabalha - um dos meios de reforma agrária prevista em Rumo à Vitória - pela política de, nas palavras de Barreto (BARRETO, 1984, p. 52), dividir os trabalhadores pelas terras. Mas esta não foi uma medida pacífica entre os trabalhadores rurais, como assinala o estudo de Barreto, que cita vários testemunhos de trabalhadores a defenderem a divisão da terra pelos trabalhadores (BARRETO, 1984, p. 52). Mas esta era a fórmula que permitiria ao PCP granjear o apoio total dos assalariados agrícolas da ZIRA garantindo uma reivindicação histórica destes homens, cuja extrema miséria foi retratada nos romances dos neo-realistas, o mais fecundo movimento literário de resistência à ditadura: o emprego permanente e para todos. Fórmula que se enquadrava também na política do PCP de manter uma estreita ligação entre o movimento social e o Estado.

É neste contexto que se vai dar a mobilização do PCP pela reforma agrária, durante a vigência do VI Governo. Depois de o partido constatar a sua marginalização no VI Governo, começa uma mobilização de base por duas políticas: permitir às UCPs acederem ao crédito agrícola para pagamento de salários e dotar os CRRA de uma verba para assegurar a atividade produtiva e a subsistência das unidades de produção. Os decretos são publicados em 27 e 29 de setembro de 1975 (crédito aos salários) e 17 e 29 de outubro (verba para os centros). E é a aprovação deste crédito que vai tornar as UCPs uma realidade.

O PCP inicia a mobilização dos assalariados agrícolas a meio de setembro e só recua no final de outubro, quando o último decreto é publicado. No dia 17 de setembro os sindicatos agrícolas fazem uma paralisação no Alentejo, apoiada no Avante! ${ }^{29}$. No dia 25 de setembro de 1975, a capa do Avante! destaca: "Defender firmemente a reforma agrária." Junto do título, uma foto de Álvaro Cunhal no Alentejo, rodeado de centenas de proletários agrícolas. A política é ofensiva. O PCP considera que há uma investida contra a reforma agrária, acusa os sectores ligados à ALA de a dirigirem e anuncia uma mobilização geral porque "não se trata apenas de não andar para trás. Há que exigir marchar em frente pois é essa a única forma de respeitar e cumprir o programa da revolução portuguesa" ${ }^{30}$. Se nas nacionalizações se tratava não de exigir novas medidas mas do seu não retrocesso, a reforma agrária aguarda concretização. De fato, durante outubro de 1975 dão-se $2 / 3$ do total das ocupações de todo o período revolucionário.

\footnotetext{
${ }^{29}$ Avante!, Série VII, 18 de setembro de 1975 , p. 1.
}

${ }^{30}$ Avante!, Série VII, 25 de setembro de 1975, p. 1. 
A 12 de outubro realiza-se o I Encontro dos Trabalhadores Metalúrgicos e Agrícolas do Sul, com mais de 8.000 delegados dos sindicatos que decidem pela paralisação do trabalho em todo o sul do país se "as medidas de apoio técnico e financeiro à Reforma Agrária não forem imediatamente concretizadas" 31 . O encontro aprova uma moção onde, entre outras vontades, expressamente se exige o uso do crédito para pagar salários:

O I Encontro dos Trabalhadores Metalúrgicos e Agrícolas do Sul aprovou uma moção segundo a qual se exige ao VI Governo Provisório que os 4 milhões de contos ainda não utilizados, dos 5 milhões destinados pelo V Governo para créditos de emergência, sejam entregues sem demora pelas Comissões Liquidatárias dos Grémios da Lavoura e agências bancárias para salários, compra de adubos, pesticidas, rações, sementes e combustíveis. ${ }^{32}$

Nesta fase o PCP exige igualmente que o VI Governo não recue nas medidas tomadas face aos camponeses do norte pelo V Governo, nomeadamente que Pinheiro de Azevedo certifique a aplicação da lei dos baldios e da abolição dos foros ${ }^{33}$.

Mas a pressão do partido vai mais longe e o PCP anuncia, nas páginas do Avante!, em 16 de outubro, a criação de uma campanha, lançada pelos dirigentes dos sindicatos agrícolas, da indústria e dos serviços, pela constituição de um Fundo Revolucionário de Apoio à Reforma Agrária, "o qual seja independente do Estado e geridos pelos próprios trabalhadores" 34 .

No dia 17, um despacho do secretário de Estado da Estruturação Agrária dota os CRRA de uma verba de 25 mil contos para assegurar a atividade produtiva dos membros das unidades de produção geridas pelos trabalhadores em vias de legalização e a 29 de outubro é publicado esse despacho.

Estava ganha, nestes moldes, a batalha do partido pela concretização da reforma agrária. As UCPs permitiram centralizar um movimento de ocupações que no quadro da crise do VI Governo sairia fora do controle do PCP. Mas a política expressa no Avante! não parece limitar-se a dirigir o movimento. Dirige-o, ofensivamente. Por isso, a outra hipótese que avançamos é que a reforma agrária granjeava um apoio de militância,

\footnotetext{
31 “Aliança dos Operários e Camponeses". In: Avante!, Série VII, 16 de outubro de 1975, p. 5.

32 "Aliança dos Operários e Camponeses". In: Avante!, Série VII, 16 de outubro de 1975, p. 5.

33 “Os camponeses do Norte exigem...". In: Avante!, Série VII, 16 de outubro de 1975, p. 5.

${ }^{34}$ Avante!, Série VII, 16 de outubro de 1975 , p. 9.
} 
de organização, de recursos estratégicos, no quadro do fim da revolução, que se avizinhava. Na ZIRA estava um apoio hegemónico ao PCP, e isso foi óbvio particularmente nos resultados eleitorais das décadas seguintes, onde só paulatina e timidamente o PS conseguiu erodir a base eleitoral do PCP aí, e mesmo assim com muitas dificuldades. Ao concretizar a reforma agrária, o PCP consolidava uma amplíssima base social e eleitoral, sem que essa medida - ao contrário do que significaria o apoio à dualidade de poderes nas fábricas ou nos quartéis - pusesse em causa a estratégia política do partido.

\section{As novas unidades de produção saídas do movimento de ocupação de terras}

Ocupadas as propriedades, os trabalhadores temporários e permanentes reúnem em plenário e, entre eles, procedem à eleição duma comissão que, a partir desse momento, passa a gerir a exploração agrícola. O que prevalece, portanto, é uma solução organizativa de natureza coletivista.

Assim, num primeiro momento, a área destas novas unidades de produção coincide com a área das explorações agrícolas ocupadas. Esta é a opção natural dos assalariados rurais. Quando há a necessidade de dotar estas herdades geridas coletivamente pelos trabalhadores duma organização formal que permita a sua legalização pelo governo, de forma a poderem aceder a diversos apoios estatais, nomeadamente crédito, formam-se as herdades coletivas, as pré-cooperativas e as UCP.

Estas diversas soluções, que só na aparência são diversas, não obedecem a qualquer modelo. Uma vez que o processo das expropriações não resulta da iniciativa do governo, nem por ele é conduzido, não há uma ideia clara sobre que tipo de organização ou que estatuto jurídico as novas unidades de produção devem ter. Isto mesmo é reconhecido no preâmbulo do Decreto-lei no 406-A/75, de 29 julho, quando aí se refere que "relega-se para próximos diplomas quer o regime das novas formas de organização da produção, quer a definição de um novo estatuto jurídico da terra, da água e da floresta em que se discipline a respectiva atribuição, uso, posse e circulação". Nesta conformidade são aceites pelo Estado todas as soluções organizativas adoptadas pelos trabalhadores.

Até outubro de 1975, ou seja, até ao início da terceira fase de ocupações, "pré-cooperativas", "herdades colectivas" e "UCP" designam a mesma realidade cuja principal característica em comum 
é a de corresponderem, em termos de área, às explorações agrícolas ocupadas.

Durante a terceira fase de ocupações, a partir de finais de outubro, esta situação vai, no entanto, alterar-se de forma substancial. Por iniciativa dos sindicatos agrícolas inicia-se um processo destinado à concentração das herdades ocupadas em grandes unidades de produção designadas por UCP, as quais, grosso modo, correspondem às terras aráveis que envolvem uma aldeia ou freguesia. A esta iniciativa dos sindicatos, os trabalhadores das terras ocupadas respondem de formas diversas.

Nos casos em que a terra é fértil, nomeadamente quando irrigada, onde uma pequena área se mostra bastante produtiva, nota-se uma resistência significativa dos assalariados rurais em integrarem-se no modelo proposto pelos sindicatos. Nestas situações ou continuam as cooperativas já formadas ou criam-se outras sob esta designação ou sob a denominação de herdades coletivas.

Nas terras predominantemente de sequeiro o processo de concentração de explorações agrícolas desenvolve-se mais facilmente sem que, no entanto, tal signifique ausência de qualquer tipo de resistência. De fato, muitas herdades não se integram logo nas UCP que se constituem nas respectivas freguesias, só o fazendo mais tarde, após processos mais ou menos longos de discussão.

Pode-se, pois, concluir que a concentração de herdades controladas pelos trabalhadores em estruturas produtivas de grande dimensão não é a opção natural dos assalariados rurais. Contudo, é esta a solução que prevalece nos campos do sul.

$\mathrm{Na}$ explicação desta realidade é comum apontar-se a ação política do PCP, o qual teria implantado nos campos do sul um modelo de inspiração soviética assente em unidades produtivas de grande dimensão tuteladas pelo Estado, capazes, com recurso à técnica, de desenvolverem ao máximo as forças produtivas e onde os trabalhadores tivessem bons salários e emprego garantido.

É inegável que este é o modelo do PCP, já referido na sua política, e também é certo ter o PCP uma forte implantação junto dos assalariados rurais e de dominar as direções dos sindicatos. No entanto, estes fatos não servem para explicar tudo, nomeadamente as razões que levam os trabalhadores agrícolas a abdicarem da sua opção natural para aceitarem a proposta que lhes é apresentada pelos sindicatos.

Na maior parte das explorações agrícolas ocupadas, nomeadamente nas grandes herdades de sequeiro, o que predomina são os trabalhadores 
eventuais, cujo número suplanta em muito o dos permanentes. Ora, os assalariados eventuais não têm patrão certo. Trabalhavam onde há emprego, embora circunscrevam a sua mobilidade às herdades que rodeiam a aldeia ou vila onde residem. Para estes é, assim, indiferente o dimensionamento das novas explorações agrícolas, desde que lhes seja garantido aquilo porque sempre tinham lutado, o emprego.

São, portanto, os trabalhadores eventuais, em maioria nas grandes herdades, os mais receptivos em aceitar a concentração de propriedades, não só porque isso lhes é relativamente indiferente, mas também, e sobretudo, porque tal solução é aquela que favorece a garantia de emprego e melhor resolve os problemas relacionados com a gestão das terras ocupadas. Dado o número reduzido de trabalhadores com experiência ao nível da direção das empresas agrícolas, o processo de concentração permite dotar as diversas explorações duma gestão com um mínimo de competência técnica.

Em síntese, do movimento de ocupações de terras ocorrido nos campos do sul, em 1975, resulta a constituição de dois tipos de novas unidades de produção: as UCP e as cooperativas agrícolas. Há ainda um terceiro tipo, as herdades estatais geridas por uma comissão administrativa nomeada pelo governo, mas não são em número significativo.

Quanto à gestão das UCP, o sistema adotado é o de comissões diretivas eleitas pelos trabalhadores. Sendo estas comissões eleitas em assembleia geral, em teoria, nada obsta a que sejam constituídas por trabalhadores duma só herdade. Contudo, na prática, não é assim que as coisas acontecem. Em regra, as direções das UCP são constituídas por delegados das comissões de trabalhadores existentes em cada uma das herdades que constituem a unidade de produção.

As cooperativas agrícolas, com uma expressão bastante reduzida, não resultam de qualquer processo de concentração de propriedades, pelo que a área ocupada coincide com as das explorações agrícolas que tinham sido alvo do controlo inicial dos assalariados rurais.

Embora UCP e cooperativas contemplem modelos diferentes quanto à gestão e organização dos trabalhadores, na prática, o seu funcionamento é muito idêntico, uma vez que quer num caso, quer no outro, os trabalhadores recebem um salário fixo, não havendo lugar, nas cooperativas, a remunerações adicionais dos cooperadores em função dos lucros.

Este aspecto do salário fixo, como forma única e exclusiva de pagamento aos trabalhadores das novas unidades de produção, é, por si só, revelador sobre quem são os protagonistas das ocupações de terras 
e os objetivos que os animam. Parece evidente que a prevalência do salário fixo sobre qualquer outra forma de remuneração é mais uma prova de que o movimento de ocupações de terras nos campos do sul tem a sua origem na luta pelo emprego e que os seus protagonistas são os trabalhadores temporários que, em todo este processo vêem a única esperança possível para uma vida melhor.

Mais tarde, dada a necessidade de a Constituição da República Portuguesa, em 1976, dar cobertura a estas novas unidades de produção, a solução encontrada é a de distinguir "as Cooperativas de trabalhadores rurais e de pequenos agricultores" do que é classificado de "outras unidades de exploração colectiva por trabalhadores", categoria esta onde se integram as UCP que, por força do art. 89 da Constituição, fazem parte do setor público. No entanto, o art. 90 integra-as, juntamente com as cooperativas, na "propriedade social", de onde são excluídas "as unidades de produção geridas pelo Estado e outras pessoas colectivas públicas".

Esta natureza jurídica das UCP, de contornos marcadamente ambíguos, só será resolvida mais tarde, quando da sua legalização sob a forma de "sociedades cooperativas".

\section{Conclusão}

Realizado o 25 de abril de 1974, num quadro de inoperacionalidade das forças repressivas do Estado, nos campos do sul constitui-se um poderoso movimento social de assalariados rurais que, de imediato, coloca junto dos grandes proprietários agrícolas, organizados na ALA, liderados pelo elemento capitalista da agricultura do sul do país, um caderno reivindicativo, cujas exigências principais são aumentos salariais e garantia de emprego.

Da luta social que daqui resulta, desenvolvida durante o verão de 1974, surge claro ser o desemprego rural o ponto em que os agricultores se mostram menos disponíveis em colaborar na sua resolução. É, pois, esta aspiração maior dos assalariados rurais temporários e a luta em torno dela, associada à resistência posta pelos agricultores em aceitarem nas suas explorações os trabalhadores desempregados, tendo como pano de fundo a grande propriedade em estado de subaproveitamento, que coloca no centro da ação reivindicativa dos trabalhadores agrícolas o pedido da expropriação dos latifúndios e das grandes empresas capitalistas, vista como a única forma possível de acesso ao pleno emprego, conviç̧ão reforçada pela intervenção pontual do Estado em algumas herdades ao abrigo do Decreto-lei no 660/74. 
Firmes neste propósito, os assalariados rurais dos campos do sul, organizados em sindicatos de base distrital, cujas direções são alinhadas politicamente com o PCP, acompanham de perto, em expectativa, a nova política agrária do Estado resultante da conjuntura políco-militar emergente do 11 de março de 1975 e, perante os atrasos e adiamentos na promulgação das medidas de reforma agrária anunciadas, por divergências existentes no interior do IV Governo Provisório, avançam para a ocupação de terras como forma de pressão sobre o poder político.

No entanto, mesmo após a publicação das chamadas "leis da reforma agrária”, em 11 de agosto de 1975, já na vigência do V Governo Provisório, o movimento de tomada de herdades não abranda. De fato, num contexto em que a expropriação desenvolvida pelo Estado, ao abrigo de Decreto-lei no 406-A/75, seria sempre morosa, o que daria espaço à concretização de processos de descapitalização nas explorações alvo de expropriação, com repercussões inevitáveis, a prazo, no desemprego rural, os trabalhadores intensificam as ocupações, agora vistas como uma espécie de aplicação da lei por antecipação.

Exemplificando o que se afirma, a análise comparada dos Quadros 1 e 2 mostra-nos haver uma diferença entre a área ocupada pelos trabalhadores e a área expropriada pelo Estado. Assim, enquanto os assalariados rurais ocupam, em 1975, segundo os dados avançados por Afonso de Barros, 1.162.434 hectares de terra, a área expropriada pelo Estado, após a publicação da última portaria expropriadora, na vigência do I Governo Constitucional (Portaria no 623/77 de 27 de setembro), cifra-se em 936.337, 6.683 hectares.

Quadro 2. Área expropriada pelo Estado

\begin{tabular}{|l|c|c|c|c|}
\hline Distritos & $\begin{array}{c}\text { Governos } \\
\text { Provisórios }\end{array}$ & $\begin{array}{c}\text { VI Governo } \\
\text { Provisório }\end{array}$ & $\begin{array}{c}\text { I Governo } \\
\text { Constitucional }\end{array}$ & Total \\
\hline Beja & & $165.742,8972$ & $2.355,6639$ & $\mathbf{1 6 8 . 0 9 8 , 5 6 1 1}$ \\
\hline Évora & $163.892,3708$ & $250.792,8954$ & $7.482,0265$ & $\mathbf{4 2 2 . 1 6 7 , 2 9 2 7}$ \\
\hline Portalegre & $34.751,5930$ & $144.222,9951$ & $5.254,8550$ & $\mathbf{1 8 4 . 2 2 9 , 4 4 3 1}$ \\
\hline Setúbal & $18.141,6395$ & $27.917,1505$ & $8.008,9946$ & $\mathbf{5 4 . 0 6 7 , 7 8 4 6}$ \\
\hline Santarém & & $82.003,6088$ & $4.312,8380$ & $\mathbf{8 6 . 3 1 6 , 4 4 6 8}$ \\
\hline Castelo Branco & & $17.671,8200$ & & $\mathbf{1 7 . 6 7 1 , 8 2 0 0}$ \\
\hline Lisboa & & $3.786,3200$ & & $\mathbf{3 . 7 8 6 , 3 2 0 0}$ \\
\hline Total & $\mathbf{2 1 6 . 7 8 5 , 6 0 3 3}$ & $\mathbf{6 9 2 . 1 3 7 , 6 8 7 0}$ & $\mathbf{2 7 . 4 1 4 , 3 7 8 0}$ & $\mathbf{9 3 6 . 3 3 7 , 6 6 8 3}$ \\
\hline
\end{tabular}

FONTE: As Portarias expropriadoras dos IV, V e VI Governos Provisórios e I Governo Constitucional (75 no total). 
Com a tomada de posse do VI Governo Provisório, há por parte dos assalariados rurais e dos seus sindicatos a percepção nítida de que no novo quadro político entretanto criado se torna importante tornar irreversível a reforma agrária no terreno, pelo que, durante o mês de outubro de 1975, desenvolve-se por todo o território da ZIRA um movimento de ocupações de terras de amplitude sem precedentes, que é favorecido pela possibilidade admitida pelo Estado de o crédito agrícola de emergência poder ser utilizado no pagamento de salários dos trabalhadores das novas unidades de produção constituídas a partir das terras ocupadas.

É ainda durante esta terceira fase de ocupações que as herdades ocupadas pelos trabalhadores se reorganizam em cooperativas e UCP, a solução dominante, e se vai cavando um fosso entre os trabalhadores agrícolas, organizados nas novas unidades de produção, e os pequenos e médios agricultores. Apesar de os sindicatos, e com eles o PCP, a força política hegemónica no seio dos assalariados rurais dos campos do sul, defenderem, em termos políticos, a aliança entre trabalhadores agrícolas e as classes intermédias da sociedade rural do sul do país, o futuro económico que se desenha nega, na prática, qualquer papel interventivo à pequena produção.

Pese embora todos os problemas com que se debateu a reforma agrária - a maioria vieram já no final de 1975, com a falta de acesso ao financiamento -, tinha-se realizado em Portugal a maior reforma agrária de sempre provocando uma mudança central, mas parcial, no modo de produção: a maximização do emprego, isto é, uma política de emprego que aumentou a produção substancialmente, trazendo ao cultivo milhares de hectares incultos.

Em 1975-76, fruto das políticas agrícolas que ficaram conhecidas no seu conjunto como reforma agrária, o número de postos de trabalho permanentes passou de 11.100 para 44.100 . O de postos de eventuais passou de 10.600 para 27.800. Nas culturas de sequeiro a área passou de 85.000 ha antes da ocupação de terras para 255.000 ha depois. O regadio passou de 7.000 hectares para 16.000. O número de tratores passou de 2.630 para 4.150 e o das máquinas de colheita de 960 para 1.720 (BAPTISTA, 2001, p. 183-184).

Naturalmente, o impacto do processo foi curto. Não havendo mudança no poder de Estado e tendo-se este estabilizado sob a égide das classes dirigentes vencedores da contrarrevolução, a reforma agrária 
estava fadada a depender das relações de forças dentro dos governos, por um lado, e, necessariamente, sujeita ao mercado, para onde era escoada a sua produção:

A economia das unidades coletivas e cooperativas estava imersa no mercado e as diversas unidades de produção dispunham de condições de produção diferenciadas - qualidade de solos, tipos de cultivo (regadio ou sequeiro), plantações, benfeitorias, melhoramentos fundiários, equipamentos, construções, máquinas. Estas desigualdades de condições provocaram uma diferenciação acentuada entre as unidades relativamente aos resultados económicos obtidos (BAPTISTA, 2001, p. 188-189).

As políticas agrárias ficaram depois dirigidas por governos que de alguma forma bloquearam o seu financiamento e a sua produção ficou sempre sujeita ao mercado. Tudo isto rapidamente desembocou numa série de problemas: conflitos dentro das cooperativas (exacerbados, segundo Oliveira Baptista, pela vaga igualitária que defendia salários iguais para todos), ausência de emprego (gerida depois pelo Fundo de Desemprego). O declínio estava garantido logo no final dos anos 70 .

\section{Referências}

BAPTISTA, Fernando Oliveira. O 25 de abril, a sociedade rural e a questão da terra. In: BRITO, José Maria Brandão. (Dir.). O País em Revolução. Lisboa: Editorial Notícias, 2001. p, 133-207.

. Portugal 1975 - Os Campos. Porto: Edições Afrontamento, 1978.

. Trabalhadores agrícolas e agricultores familiares - dez anos de factos, $\overline{\text { debates }}$ e projectos. Revista Crítica de Ciênncias Sociais, n. 18/19/20, p. 411-450, 1986.

BARRETO, António. Anatomia de uma Revolução: a reforma agrária em Portugal, 1974-1976. Mem Martins: Publicações Europa-América, 1987.

O Estado e a Reforma Agrária: 1974-1976. Análise Social, n. 77/78/79, p. 513-575, 1983.

Classe e Estado: os sindicatos na reforma agrária. Análise Social, n. 80, p. 41-96, 1984.

BARROS, Afonso de. Do Latifúndio à Reforma Agrária: o caso de uma freguesia do Baixo Alentejo. Lisboa: Fundação Calouste Gulbenkian, 1986.

CALDAS, João Castro. Terra e Trabalho. Oeiras: Celta, 2001.

CARVALHO, Lino de. Reforma Agrária: da utopia à realidade. Porto: Campo das Letras, 2004. 
CUNHAL, Álvaro. Discurso na I Conferência de Trabalhadores Agrícolas do Sul. 9 de Fevereiro de 1975. In: CUNHAL, Álvaro. Discursos Políticos (3). Lisboa: Avante!, 1975.

PIÇARRA, Constantino. As ocupações de terras no Distrito de Beja, 1974-1975. Coimbra: Almedina, 2008.

Recebido: 02 de fevereiro de 2016

Aprovado: 01 de junho de 2016

\section{Authors/Autores:}

RAQUEL VARELA <raquel cardeira_varela@yahoo.co.uk>

- Investigadora do Instituto de História Contemporânea da Universidade Nova de Lisboa, onde coordena o Grupo de História Global do Trabalho e dos Conflitos Sociais e investigadora do Instituto Internacional de História Social, onde coordena o projeto internacional In the Same Boat? Shipbuilding and ship repair workers around the World (1950-2010). É coordenadora do projeto História das Relações Laborais no Mundo Lusófono. É doutora em História Política e Institucional (ISCTE Instituto Universitário de Lisboa). Neste momento é Presidente da International Association Strikes and Social Conflicts. É vice coordenadora da Rede de Estudos do Trabalho, do Movimento Operário e dos Movimentos Sociais em Portugal. É membro da Asociacíon Historiadores del Presente. Autora de diversos artigos publicados em revistas nacionais e internacionais, além de ser autora e coordenadora de vários livros, destacando-se História do Povo na Revolução Portuguesa 1974-1975 (Bertrand, 2014); História do PCP na Revolução dos Cravos (Bertrand, 2011); Revolução ou Transição? História e Memória da Revolução dos Cravos (Bertrand, 2012); Greves e Conflitos Sociais no Portugal Contemporâneo (Colibri, 2012) e O Fim das Ditaduras Ibéricas (1974-1978) (Centro de Estudios Andaluces/ Edições Pluma, 2010). As suas áreas de investigação são História Global do Trabalho e História do Estado Social, História dos movimentos sociais na Península Ibérica, História do movimento operário português, História da Revolução de 25 de abril de 1974 e o papel do Partido Comunista Português na revolução portuguesa, além de estudo comparativo dos Partidos Comunistas Europeus.

- Researcher at the Instituto de História Contemporânea da Universidade Nova de Lisboa, where she coordinates the Grupo de História Global do Trabalho e dos Conflitos sociais and researcher of the Instituto Internacional de História Social, where she coordinates the international project In the Same Boat? Shipbuilding and Ship Repair workers around the World (1950-2010). She is the coordinator of the project História das Relações Laborais no Mundo Lusófono. She has a PhD in Political and International History (ISCTE - Instituto Universitário de Lisboa). Nowadays, she is the President of the International Association Strikes and Social Conflicts. She is the vice coordinator of the Rede de Estudos do Trabalho, do Movimento Operário e dos Movimentos Sociais em Portugal. She is member of the Asociacion Historiadores del Presente. She is the author of many books, with highlight to the works História do Povo na Revolução Portuguesa 1974-1975 (Bertrand, 2014); História do PCP na Revolução dos Cravos (Bertrand, 2011); Revolução ou Transição? História e Memória da Revolução dos Cravos (Bertrand, 2012); Greves e Conflitos Sociais no Portugal Contemporâneo (Colibri, 2012) and O Fim das Ditaduras Ibéricas (1974-1978) (Centro de Estudios Andaluces/ Edições Pluma, 2010). Her areas of research are Global History of Labor and History of the Social State, History of the social movements on the Iberian Peninsula, History of the Portuguese workers movement, History of the Revolution of April 25, 1974, the role of the Portuguese Communist Party in the Portuguese revolution and Comparative studies of the European Communist Parties.

CONSTANTINO PIÇARRA <constantino.p@sapo.pt>

- Historiador. Professor do ensino secundário e bibliotecário de leitura pública, é investigador do Instituto de História Contemporânea da Universidade Nova de Lisboa e doutorando em História Contemporânea na mesma Universidade. Tem colaborado em revistas de história e em obras coletivas com artigos sobre a questão agrária no pós 25 de abril de 1974. Sobre a temática agrária publicou As Ocupações de Terras no Distrito de Beja, 1974-1975 (Almedina, 2008) e coordenou Campos do Sul, Memória de uma Revolução, Transformaçães Económicas e Sociais, 1974-1975 (Instituto de História Contemporânea, 2009). Recentemente publicou Beja Republicana (Editora 100 Luz, 2010) e Município de Odemira na Revolução de Abril, 1974 - 1976 (Câmara Municipal de Odemira, 2015). As suas áreas de investigação são a questão agrária em Portugal no século XX, a Revolução de abril de 1974 e a extrema esquerda na revolução portuguesa.

- Secondary school teacher and librarian, he is a researcher at the Instituto de História Contemporânea da Universidade Nova de Lisboa and $\mathrm{PhD}$ candidate in Contemporary History in the same university. He has been collaborating in historical magazines and collective works in articles about the agrarian question in the post April 25, 1974. On the agrarian theme he published $A s$ Ocupações de Terras no Distrito de Beja, 1974-1975 (Almedina, 2008) and coordinated Campos do Sul, Memória de uma Revolução, Transformações Económicas e Sociais, 1974-1975 (Instituto de História Contemporânea, 2009). He recently published Beja Republicana (Editora 100 Luz, 2010) and Municipio de Odemira na Revolução de Abril, 1974 - 1976 (Câmara Municipal de Odemira, 2015). His areas of research are the agrarian question in Portugal in the $20^{\text {th }}$ Century, the Revolution of April, 1974 and the extreme left in the Portuguese Revolution. 